\title{
TINJAUAN YURIDIS JASA ANGKUTAN UMUM DENGAN APLIKASI BERBASIS TEKNOLOGI INFORMASI (PERSPEKTIF HUKUM BISNIS)
}

\author{
Siti Mariyam
}

\begin{abstract}
The phenomenon of the presence of online transportation both two wheels and four wheels today is growing very rapidly. Many people use this type of transportation with information technology (online) based applications as an option for public transportation currently in Indonesia. Transportation with information technologybased applications is actually the same as other types of public transportation (taxis) but the difference is how to order this transportation that is integrated with the internet so that it makes it easier for people to order. The community feels that they are benefitted by the presence of online transportation because of the easy way of ordering and competitive prices with convenient service. The existence of online transportation is felt to be beneficial for passengers and the public who own capital (cars). For the public, as passengers, it is facilitated by accessing the transportation at relatively cheap prices and good service, meanwhile for the community as owners of capital (cars), they have the opportunity to do business which results in additional income so as to improve welfare for the family. The presence of online transportation, although felt by many people, has many benefits, but as a business activity / business of public transportation services, the existence of online transportation needs to be regulated in a statutory regulation. The regulation is needed to provide legal certainty and protection for drivers, passengers and business people, so that it will create a sense of security, comfort and safety in accordance with the objectives of transportation in accordance with the mandate of legislation.
\end{abstract}

Keywords: Services, Public Transportation with Information Technology-Based Applications, Business Law.

\section{PENDAHULUAN}

Negara Kesatuan Republik Indonesia terdiri atas beribu pulau, terletak memanjang di garis khatulistiwa, serta di antara dua benua dan dua samudera, mempunyai posisi dan peran yang strategis untuk mendukung pembangunan ekonomi, pemantapan integrasi nasional guna memperkukuh ketahanan nasional, serta menciptakan ketertiban dunia dan

* Siti Mariyam adalah Pengajar di Fakultas Hukum UNTAG Semarang, Bidang Kajian Hukum Perdata, Sekarang sedang menempuh studi Program Doktor Ilmu Hukum UNTAG Semarang dapat di hubungi melalui: sitimariyam@untagsmg.ac.id kehidupan berbangsa dan bernegara dalam rangka memajukan kesejahteraan umum sebagaimana diamanatkan oleh UndangUndang Dasar Negara Republik Indonesia 1945.

Memajukan kesejahteraan rakyat, ${ }^{1}$ merupakan cita-cita pendiri Negara yang diikrarkan saat memproklamirkan kemerdekaan Negara Kesatuan Republik Indonesia pada tanggal 17 Agustus 1945 yang tercermin dalam Alinea IV Pembukaan Undang-undang Dasar Negara Republik Indonesia (UUD NRI) 1945. Cita-

1 Pembukaan Undang-undang Dasar Negara Republik Indonesia Tahun 1945, Alinea IV, Jakarta, Lima Adi Sekawan, 2009,Hlm. 3. 
cita tersebut merupakan pencerminan aspirasi segenap bangsa dan sekaligus merupakan amanat bagi segenap penyelenggara negara untuk mewujudkan nya dalam kehidupan bermasyarakat, berbangsa dan bernegara.Upaya mewujud kan tujuan negara tersebut hanya dapat dicapai dengan cara melakukan pemenuhan kebutuhan hidup secara memadai dengan menyelenggarakan pembangunan di segala bidang.

Transportasi mempunyai peran strategis dalam mendukung pembangunan dan integrasi nasional sebagai bagian dari upaya memajukan kesejahteraan umum. Angkutan jalan sebagai bagian dari sistem transportasi nasional harus dikembangkan potensi dan perannya untuk mewujudkan keamanan, kesejahteraan, ketertiban berlalu lintas dalam rangka mendukung pembangunan ekonomi dan pengembangan ilmu pengetahuan dan teknologi, otonomi daerah, serta akuntabilitas penyelenggara an negara.

Fungsi pengangkutan ialah memindahkan barang atau orang dari satu tempat ke tempat lain dengan maksud untuk meningkatkan daya guna dan nilai. ${ }^{2}$ Meningkatnya daya guna dan nilai merupakan tujuan dari pengangkutan, yang berarti bila daya guna dan nilai di tempat baru tidak naik, maka pengangkutan tidak perlu diadakan, sebab merupakan suatu perbuatan yang merugikan bagi pengguna jasa pengangkutan. Fungsi pengangkutan yang demikian itu tidak hanya berlaku di dunia perdagangan saja, tetapi juga berlaku di bidang pemerintahan, politik, sosial, pendidikan, hankam dan lain-lain. ${ }^{3}$

Pada era digital, pemanfaatan teknologi informasi, media dan komunikasi telah mengubah perilaku masyarakat maupun peradaban manusia secara global.

2 H.M.N. Purwosutjipto, Pengertian Pokok Hukum Dagang Indonesia 3: Hukum Pengangkutan, Jakarta, Djambatan, 1984, Hlm. 1.

3 Ibid, Hlm. 1.
Pemanfaatan teknologi informasi telah pula menyebabkan hubungan dunia menjadi tanpa batas dan menyebabkan perubahan sosial, ekonomi, dan budaya secara cepat dan signifikan. Pemanfaatan teknologi informasi dapat memberikan kontribusi bagi peningkatan kesejahteraan masyarakat dan memajukan peradaban manusia.

Pemanfaatan teknologi informasi sebagai bisnis dimungkinkan oleh Undangundang Nomor 11 Tahun 2008 yang dirubah dengan Undang-Undang Nomor 19 Tahun 2016 tentang Informasi dan Transaksi Elektronik (ITE). Pemanfaatan teknologi informasi berperan penting dalam perdagangan dan pertumbuhan ekonomi nasional untuk mewujudkan kesejahteraan masyarakat. Tujuan pemanfaatan teknologi informasi menurut Pasal 4 Undang-undang ITE antara lain adalah untuk mengembang kan perdagangan dan perekonomian nasional dalam rangka meningkatkan kesejahteraan masyarakat. Manfaat dari perkembangan teknologi informasi memberi kemudahan pada masyarakat untuk berusaha. Banyak usaha yang dijalankan dan berkembang dengan memanfaatkan kemajuan teknologi informasi, misalnya usaha di bidang angkutan yang berbasis aplikasi.

Fenomena angkutan jalan dengan sistem online merupakan perkembangan dunia transportasi dan komunikasi di seluruh dunia termasuk Indonesia. Perkembangan dunia transportasi dan komunikasi tidak terlepas dari perkembang an ilmu pengetahuan (science) dan teknologi, menyebabkan semakin berkembang inovasi di bidang transportasi yang ada di masyarakat. Masyarakat semakin mudah dan mempunyai banyak pilihan dalam menggunakan transportasi.

Salah satu contoh inovasi terbaru dalam bidang transportasi darat di Indonesia adalah Go-Jek. Mengacu pada website resmi Go-Jek, kata Go-Jek didefinisikan sebagai perusahaan berjiwa sosial yang memimpin revolusi industri 
transportasi ojek. Dalam menjalankan usahanya, Go-Jek bermitra dengan para pengendara ojek berpengalaman di Jakarta, meliputi area Jabodetabek, Bandung, Bali, Surabaya dan kota besar lainnya serta menjadi solusi utama dalam pengiriman barang, pesan antar makanan, berbelanja dan bepergian di tengan kemacetan. Seorang calon pengguna jasa Go-Jek menggunakan jasa Go-Jek melalui aplikasi yang bersifat online, di mana aplikasi GoJek untuk pengguna handphone dengan operating system iOS dan Androit dapat diakses via go-jek.com/app, inovasi transportasi yang demikian merupakan terobosan baru yang bersifat multikreatif, yang tidak hanya menjadi sumbangan bagi perkembangan transportasi nasional, tetapi juga sekaligus menciptakan lapangan pekerjaaan yang signifikan bagi masyarakat Indonesia. ${ }^{4}$ Perusahaan penyelenggara transportasi online yang terkenal di Indonesia laiinya adalah Grab. Penerusahaan aplikasi Go-Jek maupun Grab tidak hanya melayani aplikasi transportasi roda dua namun juga roda empat (Taksi Online).

Transportasi dengan aplikasi yang berbasis teknologi informasi (Transportasi online) adalah bentuk penyelenggaraan pengangkutan jalan yang cara pemesanan nya terintegrasi dengan internet. Tranportasi online merupakan fenomena baru dalam masyarakat dan bisnis transportasi. Suatu inovasi baru yang memiliki potensi menimbulkan konflik. Konflik itu bisa terjadi disebabkan persaingan bisnis antara pengemudi transportasi online dengan pelaku bisnis transportasi konvensional. Keberadaan GoJek, Uber, Grab dan yang lain-lain telah memancing protes keras dari Organisasi Pengusaha Nasional Angkutan Bermotor di Jalan (Organda) yang merupakan organisasi tunggal pengusaha di bidang

4 Andika Wijaya, Aspek Hukum Bisnis Transportasi Jalan Online, Jakarta, Sinar Grafika, 2016, Hlm. 1 angkutan jalan di Indonesia. Berikut ini beberapa contoh konflik horisontal dilapangan yang tidak dinginkan di beberapa daerah seperti: ${ }^{5}$

1. Aksi Bentrok di Medan

Adanya aksi sweeping terhadap operasional transportasi berbasis aplikasi daring (onlinne) terjadi di Medan, (Rabu 22/2/2017). Para penarik becak bermotor (bentor) melakukan sweeping kepada pengendara ojek online Go-Jek dan pengendara taksi online Grab. Salah seorang pengendara Go-Jek mendapat intimidasi hingga berujung bentrok di depan Stasiun Kereta Api Besar Medan, sedangkan salah seorang sopir Grab diserang sejumlah penarik bentor saat berada di daerah Plaza Medan Fair, Jalan Gatot Subroto, Kecamatan Medan, Kota Medan.

2. Aksi Unjuk Rasa Di Padang

Puluhan sopir angkot di Kota Padang Sumatera Barat, melakukan aksi unjuk rasa di gedung DPRD setempat menolak beroperasinya angkutan dalam jaringan (daring) di daerah itu. Ratusan sopir angkot mulai melakukan aksi mogok di depan DPRD pada pukul 09.30 WIB. Tuntutan para sopir angkot lebih difokuskan kepada angkutan daring jenis mobil seperti Go-Car, Garb, dan Uber;

Perwakilan sopir angkot (Direktur PT. Permata Biru) mengatakan agar pemerintah dapat menertibkan angkutan daring yang beroperasi di Padang dan

5 Direktori Putusan Mahlkamah Agung Republik Indonesia Nomor $15 \mathrm{P} / \mathrm{HUM} / 2018$ Mengenai Keberatan Hak Uji Materiil Terhadap Pasal 27 ayat (1) huruf c, d, ayat (2), Pasal 28 ayat (1), ayat (2), ayat (3), ayat (4), dan ayat (5), Pasal 38 huruf $\mathrm{a}$, huruf $\mathrm{b}$, huruf $\mathrm{c}$, Pasal 39 ayat (1), ayat (2), Pasal 40, Pasal 48 ayat (10) huruf b angka 2, Pasal 48 ayat (11) huruf b angka 3, Pasal 65 huruf $\mathrm{c}$ dan e, Pasal 72 ayat (5) huruf c dan Pasal 80 Peraturan Menteri Perhubungan Republik Indonesia Nomor PM 108 Tahun 2017 tentang Penyelengaraan Angkutan Orang Dengan Kendaraan Bermotor Umum Tidak Dalam Trayek, Hlm. 53-63. 
mohon pada pemerintah untuk menetapkan tarif angkutan daring.

3. Aksi Massa di Makasar

Ratusan massa yang terdiri sopir petepete (angkot) dan pebentor melakukan aksi massa di depan Gurbenuran Sulawesi Selatan, menolak angkutan umum berbasis online. Para sopir menahan kendaraan roda empat plat hitam, aksi tersebut sempat membuat para pengendara roda empat ketakutan. Beberapa kali aksi unjuk rasa dilakukan oleh sopir pete-pete dan pebentor, tapi terus digagalkan pihak kepolisian. Dalam aksi gabungan para sopir menyampaikan tuntutan penghentian layanan transportasi online dan pemberlakuan Pearturan Menteri Perhubungan Nomor 108 Tahun 2017 tentang Penyelenggaraan Angkutan Orang Dengan Kendaraan Bermotor Umum Tidak Dalam Trayek.

4. Aksi Sweeping di Surabaya

Para sopir angkutan umum konvensional menggelar demonstrasi di Surabaya, sempat melakukan sweeping terhadap sejumlah angkuan online dan juga angkutan konvensional yang beroperasi. Selain itu beberapa pengemudi ojek berbasis aplikasi online juga dihadang dan menjadi sasaran massa demonstran. Aksi tersebut segera dibubarkan oleh Polisi. Aksi sopir angkutan kota Surabaya membuat operator angkutan online tidak bekerja untuk sementara waktu, hal ini dilakukan untuk menjaga keamanan dan keselamatan pengemudi taksi online dan operator itu sendiri.

5. Aksi Mogok dan Turun Jalan di Solo Ratusan pengemudi taksi melakukan aksi mogok dan turun ke jalan memprotes beroperasinya taksi berbasis aplikasi (online). Peserta aksi terdiri dari pengemudi taksi dari lima perusahaan taksi yang ada di Solo yaitu Gelora, Kosti, Sakura, Mahkota, dan Wahyu Taksi yang tergabung dalam Barisan
Anti Angkutan Ilegal Solo Raya. Peserta aksi berkumpul di Bundaran Gladag di Jalan Slamet Riyadi Solo, kemudian mendatangi Kantor Balai Kota Solo dan menggelar orasi dan happening art. Para peserta aksi meendesak pemerintah agar segera mengatasi keberadaan taksi online yang sudah mempengaruhi pendapatan para pengemudi taksi konvensional.

Gambaran aksi bentrok, aksi unjuk rasa, aksi sweeping dan demo di atas merupakan kondisi nyata yang terjadi, maka negara wajib hadir untuk memberikan pengaturan terhadap transportasi online sehingga transportasi berbasis aplikasi mempunyai payung hukum dan dapat berjalan harmonis dengan moda-moda transportasi lainnya. Guna memberi kepastian hukum pada transportasi online maka pemerintah melalui Menteri Perhubungan mengeluar kan beberapa peraturan tentang transportasi online, terakhir pemerintah mengeluarkan Peraturan Menteri Perhubungan Nomor 107 Tahun 2017 tentang tentang Penyelenggaraan Angkutan Orang dengan Kendaraan bermotor Umum Tidak Dalam Trayek, namun Peraturan Menteri Perhubungan Nomor 108 tahun 2017 telah dibatalkan oleh Mahkamah Agung. Bulan Desember tahun 2018 Kementrian Perhubungan mengeluarkan regulasi untuk transportasi/taksi online yaitu Permenhub Nomor 118 Tahun 2018 tentang Penyelenggaraan Angkutan Sewa Khusus yang berlaku mulai bulan Mei tahun 2019.

Kehadiran transportasi online di banyak negara juga menimbulkan permasalahan tersendiri yang memunculkan konflik terutama konflik dengan angkutan reguler atau eksisting. Berikut merupakan gambaran awal saat kehadiran transportasi online di beberapa negara: ${ }^{6}$

6 https://www.shopback.co.id/blog/7-protestransportasi -online-di-luar-negeri-yang pernah terjadi, diakses tanggal 4 Januari 2019. 
1. Paris, Perancis

Pada bulan Juli 2015, persatuan taksi Perancis dan Uber terlibat dalam konflik, dalam aksi tersebut diwarnai dengan pemblokiran jalan raya. Demonstrasi terjadi di segala penjuru Paris dan pemblokiran akses menuju bandara dan stasiun kereta api di Paris.

Seluruh tuntutan dan protes ditujukan kan kepada pemerintah dan perusahaan Uber yang dirasa telah mengancam kelangsungan taksi konvensional. Pemerintah dinilai tak tidak berbuat banyak untuk membuat persaingan usaha menjadi sehat kembali. Dalam menghadapi aksi protes tersebut, Uber pun mengirimkan surat elektronik kepada para pengguna jasa untuk turut mendorong terbentuknya peraturan yang adil bagi kedua belah pihak. Tentunya, kebijakan pemerintah yang berkeadilan menjadi kunci untuk meminimalisir konflik yang bisa saja terjadi kembali, serta memastikan bahwa semua pihak merasakan keadilan yang sama.

2. Brussel, Belgia

Taksi konvensional dan Uber di Belgia pun turut terlibat dalam konflik. Protes yang dilayangkan mengenai ketidak adilan yang ada dalam kompetisi antara kedua jenis kendaraan tersebut. Aksi protes anti Uber terus menyuarakan ketidakadilan yang telah terjadi akibat kemunculan UberPOP, salah satu penyedia jasa transportasi sangat murah yang membuat penyedia jasa taksi konvensional kehilangan pelanggan secara drastis.

Demontrasi melibatkan ribuan sopir taksi konvensional dan tersebar di beberapa titik di Belgia. Aksi dilakukan secara serentak, akhirnya keluar kebijakan pemerintah menarik izin operasioanal UberPOP dan melarang UberPOP beroperasi di Belgia.

3. Kuala Lumpur, Malaysia

Bulan Juni tahun 2016, para pengemudi transportasi konvensional melakukan protes terhadap pengemudi taksi online seperti taksi Uber dan taksi Grab. Protes terhadap pengemudi taksi online dilakukan oleh 200 pengemudi taksi selama 4 (empat) jam di George Town. Tujuan dari protes ini adalah untuk meminta pemerintah untuk tidak melegalkan aplikasi Uber dan aplikasi Grab beroperasi di Malaysia karena aplikasi transportasi online tersebut dianggap merusak bisnis transportasi konvensional. Aplikasi transportasi Grab dibangun di malaysia, namun tetap saja para pengemudi taksi konvensional tidak dapat menerima kehadiran aplikasi transportasi online.

Adanya fenomena pro kontra serta konflik kehadiran transportasi berbasis online di berbagai negara tersebut di atas, memberi gambaran bahwa kehadiran transportasi online perlu diatur dengan sebuah peraturan yang akan memberikan kepastian berusaha dan perlindungan hukum pada pelaku usaha transportasi online, mengingat kehadiran transportasi online ber manfaat bagi masyarakat dalam mengakses transportasi dan membuka kesempatan kerja sehingga dapat meningkatkan kesejahteraan masyarakat. Kehadiran transportasi online dibutuhkan masyarakat terbukti dari hasil survey online yang dilakukan oleh Yayasan Lembaga Konsumen Indonesia (YLKI) yang dilaksanakan pada tangal 5-16 April 2017 yang melibatkan 4.668 responden. Hasil survey tersebut mengatakan, bahwa alasan utama responden memilih menggunakan transportasi online adalah: murah ( 84,1 persen), cepat $(81,9$ persen), nyaman ( 78,8 persen) dan aman $\left(61,4\right.$ persen). ${ }^{7}$ Masyarakat menganggap

\footnotetext{
7 http://wartakota,tribunenews.com/amp/2017/05/12/inihasil-lengkap-survey-transportasi-online-ylki-41-persenpengguna-pernah-dikecewakan, diakses tanggal 22 September 2018
} 
keberadaan transportasi online ini memberi keuntungan dalam memilih transportasi, namun demikian transportasi online perlu diatur guna memberi perlindungan hukum terhadap aspek keselamatan bagi penumpang, pengemudi dan kepastian hukum berusaha bagi pelaku usaha. Perkembangan angkutan jalan berbasis aplikasi menyebabkan benturan kepentingan antar masyarakat, antar pelaku usaha, bahkan benturan kepentingan dengan negara yang perlu diatur dengan hukum. Transportasi online dapat memberi manfaat pada masyarakat namun di sisi lain dirasakan menimbulkan ketidakadilan bagi penyelenggara transportasi konvensional, bagi penumpang selaku konsumen tidak ada perlindungan terhadap aspek keselamatan sesuai dengan tujuan Undang-undang LaluLntas dan Angkutan Jalan, oleh karena itu perlu dikaji mengenai Tinjauan Yuridis Jasa Angkutan Dengan Aplikasi Berbasis Teknologi Informasi (PersepktifHukum Bisnis).

\section{Pembahasan}

Dalam kehidupan sehari-hari pengangkutan selalu dimanfaatkan oleh setiap orang baik untuk kepentingan pribadi maupun usaha/bisnis. Pengangkutan dimanfaatkan untuk menunjang dan memperlancar kehiupan dan bisnis manusia, dengan pengangkutan orang dan/atau barang dapat berpindah dari satu tempat ke tempat tujuan dengan selamat dan berhasil guna. Fungsi pengangkutan ialah memindahkan barang atau orang dari satu tempat ke tempat lain dengan maksud untuk meningkatkan daya guna dan nilai. ${ }^{8}$ Meningkatnya daya guna dan nilai merupakan tujuan dari pengangkutan, yang

8 H.M.N. Purwosutjipto, Pengertian Pokok Hukum Dagang Indonesia 3: Hukum Pengangkutan, Jakarta, Djambatan, 1984, Hlm. berarti bila daya guna dan nilai di tempat baru tidak naik, maka pengangkutan tidak perlu diadakan, sebab merupakan suatu perbuatan yang merugikan bagi pengguna jasa pengangkutan. Fungsi pengangkutan yang demikian itu tidak hanya berlaku di dunia perdagangan saja, tetapi juga berlaku di bidang pemerintahan, politik, sosial, pendidikan, hankam dan lain-lain.'

Pengangkutan adalah perjanjian timbal-balik antara pengangkut dengan pengirim, di mana pengangkut mengikat kan diri untuk menyelenggarakan pengangkutan dan/atau orang dari suatu tempat ke tempat tujuan tertentu dengan selamat, sedangkan pengirim/penumpang mengikatkan diri untuk membayar uang angkutan. ${ }^{10}$ Pihak-pihak pengangkutan adalah pengangkut dan pengirim/ penumpang. Perjanjian pengangkutan bersifat timbal balik, kedua belah pihak mempunyai kewajiban sendiri-sendiri. Pengangkut berkewajiban menyelenggara kan pengangkutan barang dan/atau orang dari satu tempat ke tempat tujuan tertentu dengan selamat, sedangkan kewajiban pengirim/penumpang adalah membayar uang angkutan. Jika dalam pengangkutan tidak selamat menjadi tanggung jawab pengangkut.

Jenis-jenis pengangkutan yang dikenal dan peraturan perundangundangannya adalah sebagai berikut: Pengangkutan darat diatur dalam Undangundang Nomor 22 Tahun 2009 Tentang Lalu Lintas dan Angkutan Jalan, Pengangkutan dengan kereta api diatur dalam Undang-undang Nomor 23 Tahun 2007 Tentang Perkeretaapian, Pengangkutan Laut yang diatur dalam Undang-undang Nomor 17 Taun 2008 Tentang Pelayaran, dan pengangkutan udara diatur dalam Undang-undang Nomor 1 Tahun 2009 Tentang Penerbangan.

Pengangkutan darat diatur berdasarkan Undang-undang Nomor 22

9 Ibid, Hlm. 1.

10 Ibid, Hlm. 2 
Tahun 2009 Tentang Lalu Lintas dan Angkutan Jalan yang diundangkan dalam Lembaran Negara Republik Indonesia Nomor 96 Tahun 2009 pada tanggal 22 Juni 2009 di dalamnya memuat pengertian pengangkutan. Pengertian angkutan menurut Pasal 1 angka (3) Undang-undang Nomor 22 Tahun 2009 adalah perpindahan orang dan/atau barang dari satu tempat ke tempat lain dengan menggunakan kendaraan di ruang lalu lintas jalan. Lalu lintas dan angkutan jalan diselenggarakan dengan memperhatikan asas transparansi, asas akuntabel, asas berkelanjutan, asas partisipatif, asas bermanfaat, asas efisien dan efektif, asas seimbang, asas terpadu dan asas mandiri.

Tujuan penyelenggaraan angkutan jalan terdapat dalam ketentuan Pasal 3 point (a) Undang-undang Nomor 22 Tahun 2009 tentang Lalu-Lintas dan Angkutan Jalan bahwa: "Lalu lintas dan angkutan jalan diselenggarakan dengan tujuan terwujud nya pelayanan lalu lintas dan angkutan jalan yang aman, selamat, tertib, lancar, dan terpadu dengan moda angkutan lain, untuk mendorong perekonomian nasional, memajukan kesejahteraan umum, memperkukuh persatuan dan kesatuan bangsa, serta mampu menjunjung tinggi martabat bangsa. Point (b), Lalu lintas dan angkutan jalan diselenggarakan dengan tujuan terwujudnya penegakan hukum dan kepastian hukum bagi masyarakat.

Angkutan orang dan/atau barang dapat menggunakan kendaraan bermotor dan kendaraan tidak bermotor. Untuk angkutan orang yang menggunakan kendaraan bermotor berupa sepeda motor, mobil penumpang, atau bus. Penyeleng garaan angkutan umum diselenggarakan dalam upaya memenuhi kebutuhan angkutan yang selamat, aman, nyaman, dan terjangkau. Pasal 139 ayat (4) Undangundang Nomor 22 Tahaun 2009, memuat ketentuan bahwa penyediaan jasa angkutan umum dilaksanakan oleh badan usaha milik negara, badan usaha milik daerah, dan atau badan hukum lain yang sesuai ketentuan perundang-undangan. Ketentuan ini dipertegas dalam Pasal 79 Peraturan Pemerintah No. 74 Tahun 2014 tentang Angkutan Jalan, menentukan secara imperatif, bahwa perusahaan angkutan umum menyelenggarakan angkutan orang dan/atau barang harus berbentuk badan hukum Indonesia sesuai dengan perundang-undangan. ${ }^{11}$ Demikian pula dengan transportasi online sebagai perusahaan jasa di bidang angkutan sudah harus mengikuti ketentuan Undang-undang lalu Lintas dan Angkutan Jalan dan peraturan pelaksananya.

Regulasi transportasi online diperlukan guna memberi payung hukum yang dapat memberi kepastian hukum bagi pelaku usaha transportasi online menjalankan usahanya. Pada tanggal 9 November 2015 Menteri Perhubungan Ignasius Jonan mengeluarkan Surat Pemberitahuan Nomor : UM.3012/1/21/ Phb/2015. Salah satu point penting dari Surat Pemberitahuan tersebut terletak pada point 2 (dua) yang berbunyi:

"Pengaturan kendaraan bermotor bukan angkutan umum tersebut di atas sesuai dengan ketentuan UU No. 22 Tahun 2009 tentang Lalu Lintas dan Angkutan Jalan dan PP No. 74 Tahun 2014 tentang Angkutan Jalan tidak memenuhi kendaraan sebagai angkutan umum." 12

11 Bentuk-bentuk badan hukum Indonesia berdasarkan perundang-undangan yaitu, Badan Usaha Milik Negara (BUMN), Badan Usaha Milik Daerah (BUMD), Perseroan Terbatas (PT), dan Koperasi. Jika badan hukum Koperasi maka koperasi yang memiliki unit usaha di bidang angkutan jalan. Adapun perizinan di bidang penyelenggaraan angkutan jalan berdasar undang-undang dibedakan menjadi tiga yaitu, angkutan orang dalam trayek, angkutan orang tidak dalam trayek, dan penyelenggaraan angkutan barang khusus.

12 https://archive.org / stream / Undang-undang Nomor 22 Tahun 2009 lalu-Lintas Dan Angkutan Jalan / UU Nomor 22 Tahun 2009-LLAJdjvu.txt, diakses tanggal 1 September 2018. 
Keluarnya Surat Pemberitahuan Nomor: UM.3012/1/21/Phb/2015 tertanggal 9 November 2015, telah banyak menuai dukungan, kritik hingga kecaman dari berbagai pihak melalui media tulis dan media elektronik. Hal ini disebabkan di dalam Surat Pemberitahuan Nomor: UM.3012/1/21/Phb/2015 tersebut di atas, Menteri Perhubungan menyatakan bahwa kendaraan bermotor bukan angkutan umum sebagai mana tersebut dalam UU No. 22 Tahun 2009 tentang Lalu Lintas dan Angkutan Jalan. Tindakan Menteri Perhubungan Republik Indonesia merupakan sebuah bentuk pelaksanaan atau kepatuhan terhadap peraturan perundangundangan di bidang transportasi berbenturan dengan suara keadilan masyarakat, yang menyebabkan benturan kepentingan antara penyelenggara angkutan jalan konvensional dan online, berujung pada kejadian-kejadian yang tidak diinginkan yang berkaitan dengan munculnya tindakan-tindakan vandalism. ${ }^{13}$

Tahun 2016 Menteri Perhubungan mengeluarkan Peraturan Menteri Perhubungan (Permenhub) Nomer 26 Tahun 2016 yang berisi bahwa penyelenggaraan barang kendaraan bermotor umum dalam trayek diatur ketentuan tarif batas atas, tarif batas bawah, dan Surat Tanda Nomer Kendaraan (STNK) badan hukum. Diberlakukannya Permenhub Nomer 26 Tahun 2016 pada 1 April 2017 merupakan cara pemerintah untuk memberi solusi mengakhiri konflik transportasi online dan konvensional. Belum berlaku Permenhub ini direspons negatif oleh Uber, Go-Jek, dan Grab. Pemerintah dianggap gagap terhadap kebaruan yang diperkenalkan oleh perusahaan teknologi. Dengan klaim bahwa pembaruan dalam penyedia jasa transportasi Permenhub tersebut dianggap sebagai sebuah kemunduran. ${ }^{14}$

13 Loc. Cit, Hlm. 4-5.

$14 \mathrm{https}: / /$, diakses tanggal 2 Oktober 2018.
Hasilnya Permenhub Nomer 26 Tahun 2016 yang dicabut oleh Mahkamah Agung dalam Putusan MA Nomor 37/P.HUM/2017 tanggal 20 Juni 2017, dan karenanya tidak sah dan tidak berlaku umum.

Kemudian Tahun 2017 Menteri Perhubungan mengeluarkan Permenhub Nomer 108 Tahun 2017 tentang Penyelenggaraan Angkutan Orang dengan Kendaraan bermotor Umum Tidak Dalam Trayek termasuk taksi online melakukan uji KIR, pengemudi memiliki SIM A Umum, dan pasang stiker di mobil. Permenhub Nomer 108 Tahun 2017 ini sebagai pengganti Permnehub Nomer 26 Tahun 2016. Permenhub tersebut sebagai wujud keseriusan pemerintah dalam mengatur transportasi online agar bisa berusaha sebagaimana transportasi konvensional secara aman, lancar, dan selamat.

Pada 12 September 2018 Peraturan Menteri Perhubungan Nomor 108 Tahun 2017 dicabut oleh Mahkamah Agung (MA) dalam Putusan MA Nomor 15/P.HUM/ 2018 dengan perrtimbangan Peraturan Menteri Perhubungan Nomor 108 Tahun 2017 tentang Penyelenggaraan Orang Dengan Kendaraan Bermotor Umum Tidak Dalam Trayek, merupakan pemuatan ulang materi norma yang telah dibatalkan oleh Putusan MA Nomor 37/P.HUM/2017 tanggal 20 Juni 2017, dan karenanya tidak sah dan tidak berlaku umum. ${ }^{15}$

Dibatalkannya Permenhub Nomor 108 Tahun 2017 menyebabkan terjadinya kekosongan hukum yang mengatur tentang transportasi online. Ketiadaan peraturan taksi online ini berakibat tidak ada kepastian hukum bagi bisnis transportasi online, namun Desember 2018 Kementrian Perhubungan kembali mengeluarkan Permenhub Nomor 118 Tahun 2018 tentang Penyelenggaraan Angkutan Sewa Khusus

15 http://detik.id/6CH6IK, MA Kembali cabut AturanTransportasi online, diakses tanggal 12 September 2018. 
yang mengatur tentang taksi online dan berlaku mulai bulan Mei tahun 2019. Menurut Permenhub Nomor 118 Tahun 2018 angkutan dengan aplikasi berbasis teknologi informasi (Taksi Online) harus memenuhi Standar Pelayanan Minimal (SPM). Standar Pelayanan Minimal ini bertujuan untuk memberikan perlindungan kepada penumpang. Dalam Standar Pelayanan Minimal ada ketentuan yang mewajibkan pelaku usaha membayar iuran jasa raharja.

\section{Kesimpulan}

Bisnis angkutan berbasis aplikasi/ transportasi online memberi dampak positif yaitu dapat menciptakan lapangan kerja dan meningkatkan kesejahteraan masyarakat. Keberadaan transportasi online bermanfaat bagi masyrakat namun perlu diatur regulasi yang jelas sehingga dapat memberikan perlindungan dan kepastian hukum pada penumpang, pengemudi dan pelaku usaha dalam menyelenggarakan bisnisnya. Megingat transportasi online ini secara substansi belum diatur dalam UU Nomor 22 Tahun 2009 tentang Undang-undang Lalu Lintas dan Angkutan Jalan, secara stukrtur, pihak yang berkompeten di bidang transportasi darat belum tegas dalam melakukan tindakan yang sesuai dengan peraturan perundang-undangan, sedangkan secara kultur/budaya, masyarakat sudah menggunakan transportasi jenis ini.

\section{Daftar Pustaka}

Abdul Halim Barakatullah dan Teguh Prasetyo, Bisnis E-commerce, Studi Sistem Keamanan dan Hukum Di Indonesia, Yogyakarta, Pustaka Pelajar, Cetakan kedua, 2006.

Andika Wijaya, Aspek Hukum Bisnis Transportasi Jalan Online, Jakarta, Sinar Grafika, 2016.

Dian Mega Erianti Renouw, Perlindungan Hukum E-Commerce,Perlindungan
Hukum Pelaku Usaha dan Konsumen E-Commerce Di Indonesia, Singapura, dan Australia, Jakarta, Pramuka Grafika, 2016.

Djaya Bakri, Transportasi Multimoda: Sebuah Pemodelan Kebutuhan Transportasi Multimoda, Malang, Inti Media, 2016

Dominikus Plato, Filsafat Hukum, Mencari, Menemukan, dan Memahami Hukum, Surabaya, Laksbang Yustisia, 2010.

E. Fernando M Manuliang, Menggapai Hukum Berkeadilan, Jakarta, Buku Kompas, 2007.

Firman Tumantara Endipradja, Hukum Perlindungan Konsumen: Filosofi Perlindungan Konsumen Dalam Perspektif Politik Hukum Negara Kesejahteraan, Malang, Setara Press, 2016.

Harris Turino, Meretas Konsep Ekonomi Berbagi (Unveiling The Concept of Sharing Economy), Tangerang Selatan, Kesuma Putra Kreatif, Cetakan Kedua, 2016.

H.A. Abbas Salim, Manajemen Transportasi, Jakarta, Raja Grafindo Persada, Cetakan Kesebelas, 2013.

H.M.N. Purwosutjipto, Pengertian Pokok Hukum Dagang Indonesia 3: Hukum Pengangkutan, Jakarta, Djambatan, 1984.

H.M.N. Purwosutjipto, Pengertian Pokok Hukum Dagang Indonesia 1: Pengetahuan Dasar Hukum Dagang, Jakarta, Djambatan, 1999.

H. Salim HS dan Erlies Septiana Nurbani, Penerapan Teori Hukum Pada PenelitianTesis dan Disertasi, Buku Kesatu, Jakarta, PT. Raja Grafindo, 2013.

H. Salim HS dan Erlies Septiana Nurbani, Penerapan Teori Hukum Pada PenelitianTesis dan Disertasi, Buku Ketiga, Jakarta, PT. Raja Grafindo, Cetakan Kedua, 2017. 
Satjipto Raharjo, Ilmu Hukum, Bandung, Pt. Citra Aditya Bakti, 2000.

Pembukaan Undang-Undang Dasar Negara Republik Indonesia Tahun 1945, Alinea IV, Jakarta, Lima Adi Sekawan, 2009.

Undang-Undang Nomer 8 Tahun 1999 Tentang pelindungan Konsumen.

Undang-undang Nomor 11 Tahun 2008 yang diubah dengan Undang-undang Nomor 19 Tahun 2016 Tentang Informasi dan Transaksi Elektronik.

Undang-undang Nomer 22 tahun 2009 Tentang Lalu-Lintas dan Angkutan Jalan .

Peraturan Pemerintah Nomer 82 Tahun 2012 Tentang penyelenggaraan Sistem dan Transaksi Elektronik.

Peraturan Pemerintah Nomor 74 Tahun 2014 Tentang Penyelenggaraan Sistem Angkutan Jalan.
Putusan Mahkamah Agung Republik Indonesia Nomor 15 P/HUM/2018 tentangYudicial Review Permenhub. Nomor 108 Tahun 2017.

https://www.shopback.co.id/blog/7protes-transportasi-online-di-luarnegeri-yang pernah terjadi.

http://detik.id/6CH6IK, MA Kembali cabut Aturan Transportasionline.

https://archive.org / stream / Undangundang Nomor 22 Tahun 2009 laluLintas Dan Angkutan Jalan / UU Nomor 22 Tahun 2009-LLAJdjvu.txt.

http://wartakota,tribunenews.com/amp/20 17/05/12/ini-hasil-lengkap-surveytransportasi-online-ylki-41-persenpengguna-pernah-dikecewakan. 